\title{
PENGETAHUAN PERAWAT MELAKUKAN PERENCANAAN KEPERAWATAN DAN IMPLEMENTASI DALAM PROSES KEPERAWATAN
}

\author{
Pebi Septrian Sari \\ febi.septrian@gmail.com
}

\section{LATAR BELAKANG}

Keperawatan adalah profesi unik yang memiliki fokus utama caring,yaitu bagaimana memberi dan mengelola asuhan yang dibutuhkan oleh pasien. Perawat sebagai salah satu faktor yang mempengaruhi asuhan keperawatan dan merupakan faktor yang paling menentukan untuk tercapainya pelayanan kesehatan yang berkualitas dengan asuhan keperawatan yang bermutu. Mutu asuhan yang unggul dapat memenuhi kebutuhan masyarakat terhadap kesehatan. Dalam memberikan pelayanan, perawat memberikan asuhan keperawatan yang terangkum dalam satu siklus yaitu proses keperawatan.

Pelaksanaan asuhan keperawatan yang simultan tersebut akan mendatangkan implikasi terhadap tingkat kepuasan klien. Salah satu ciri profesionalisme adalah adanya cara kerja profesional setiap subyek yang ada di dalamnya dan diantaranya didukung dengan dokumentasi yang akurat, jelas, terpercaya dan sah secara hukum. Asuhan keperawatan adalah kerangka kerja dan struktur organisasi yang kreatif untuk memberikan pelayanan keperawatan, namun asuhan keperawatan juga cukup fleksibel untuk digunakan disemua lingkup keperawatan (Potter \& Perry, 2005). Asuhan ini diberikan melalui metode yang disebut proses keperawatan.

Proses keperawatan dapat digunakan sebagai pedoman dalam pemecahan masalah pada klien, dapat menunujukkan profesi yang memiliki profesionalitas yang tinggi, serta dapat memberikan kebebasan pada klien untuk mendapatkan pelayanan yang cukup sesuai dengan kebutuhannya. Proses keperawatan mengandung elemen berpikir kritis yang memungkinkan perawat dapat melakukan tindakan berdasarkan penalaran. Penerapan proses keperawatan dalam asuhan keperawatan kepada pasien merupakan tanggung jawab dan tanggung gugat perawat kepada pasien. Sebelum melakukan proses keperawatan perawat terlebih dahulu membuat tahap perencanaan keperawatan setelah menentukan diagnosis keperawatan untuk memberi asuhan keperawatan yang baik.

Setelah melakukan diagnosa keperawatan, langkah selanjutnya perawat melakukan Perencanaan atau intervensi keperawatan. Perencanaan keperawatan merupakan penyusunan rencana tindakan keperawatan yang akan dilakukan untuk mencegah, mengurangi dan mengatasi masalah- masalah yang telah diidentifikasi dalam diagnosa keperawatan. Dalam menentukan tahap perencanaan bagi perawat diperlukan berbagai pengetahuan tentang kekuatan dan kelemahan klien, nilai dan kepercayaan klien, batasan praktek keperawatan, peran dari tenaga kesehatan lainnya, kemampuan dalam memecahkan masalah, mengambil keputusan, menulis tujuan serta memilih dan membuat strategi keperawatan yang aman dalam memenuhi tujuan, menulis intruksi keperawatan serta kemampuan dalam melaksanakan kerja sama dengan tingkat kesehtan lain (Supratti dan Ashriady, 2016). 
Desain perencanaan menggambarkan sejauh mana perawat mampu menetapkan cara menyelesaikan masalah dengan efektif dan efisien. Rencana keperawatan merupakan metode komunkasi tentang asuhan keperawatan kepada klien. Setiap klien memerlukan asuhan keperawatan perlu suatu perencanaan yang baik. Dalam buku Potter \& Perry, Langkah langkah dalam membuat perencanaan keperawatan meliputi : penetapan prioritas, penetapan tujuan dan kriteria hasil yang diharapkan, menentukan intervensi keperawatan yang tepat dan pengembangan rencana asuhan keperawatan. Setelah diagnosa keperawatan dirumuskan secara spesifik, perawat menggunakan kemampuan berfikir kritis untuk segera menetapkan prioritas diagnosa keperawatan dan intervensi yang penting sesuai dengan kebutuhan klien.

Tahap proses keperawatan selanjutnya adalah Implementasi. Implementasi merupakan pelaksanaan atau perwujudan dari intervensi yang sudah ditetapkan dengan tujuan yang sama yaitu untuk memenuhi kebutuhan pasien dan meningkatkan status kesehatannya. Implementasi keperawatan melaui tahap persiapan, intervensi, dan dokumentasi. Pengetahuan, pendidikan dan Motivasi perawat merupakan landasan utama dalam melaksanakan pelayanan atau asuhan keperawatan yang professional sehingga perlu diteliti hubungan pengetahuan, pendidikan dan motivasi perawat dengan pelaksanaan asuhan keperawatan spiritual. Pelayanan keperawatan yang buruk dapat menimbulkan kurangnya kepercayaan masyarakat terhadap kemampuan rumah sakit. Di samping itu, kinerja perawat dalam melaksanakan asuhan keperawatan yang rendah juga merupakan hambatan terhadap perkembangan keperawatan menuju perawat yang professional.

\section{METODE}

Rancangan penelitian yang digunakan adalah literature review. Dengan melakukan analisis dan kajian bebas pada jurnal, e-book, maupun buku teks yang berkaitan dengan materi pembelajaran yaitu perencanaan dalam proses keperawatan yang mana perencanaan dalam proses keperawatan ini berkaitan untuk menegetahui tindakan yang harus dilakukan perawat dalam memberi asuhan keperawatan.

Bahan kajian yang digunakan pada literature review ini adalah jurnal atau artikel yang didapatkan dari google scholar. Dengan menggunakan 10 sumber referensi jurnal yang diterbitkan pada 10 tahun terakhir. Dalam mencari literature reviewnya, menggunakan kata kunci proses keperawatan, intervensi keperawatan, dan perawat.

\section{HASIL}

Berdasarkan hasil studi literatur, diketahui bahwa komponen diagnosa dijadikan sebagai pedoman perawat dalam memberikan asuhan keperawatan yang berkualitas dalam proses keperawatan. Langkah sebelum melakukan implementasi keperawatan adalah intervensi atau perencanaan dimana dapat diketahui berdasarkan diagnosa yang telah dilakukan. Diagnosa keperawatan dijadikan sebagai proses yang menitikberatkan pada aspek pengkajian dan pengumpulan data untuk mendiagnosis masalah keperawatan pasien berdasarkan yang dikeluhkan seperti pemeriksaan fisik pasien dan pemeriksaan penunjang. 
Dalam melakukan tahap perencanaan perawat perlu memiliki pengetahuan. Di dapatkan hasil bahwa adanya hubungan antara pengetahuan dengan proses keperawatan. Pengetahuan perawat yang baik, karena memiliki tingkat pendidikan serta turut menentukan mudah tidaknya seseorang menyerap dan memahami pengetahuan yang mereka peroleh.

\section{PEMBAHASAN}

Pengetahuan merupakan hasil tahu dan terjadi setelah orang melakukan penginderaan terhadap suatu objek tertentu. Penginderaan terjadi melalui panca indera yaitu indera penglihatan, pendengaran, penciuman, rasa dan raba. Dapat diketahui pengetahuan perawat dalam memahami asuhan keperawatan $(46,88 \%)$ memiliki pengetahuan cukup, pengetahuan perawat pada diagnosa keperawatan $(34,37 \%)$ memiliki pengetahuan cukup, pada perencanaan didapatkan orang $(37,50 \%)$ memiliki pengetahuan baik, sedangkan pada implementasi sebanyak (28,13\%). Pengetahuan perawat secara keseluruhan dalam memahami asuhan keperawatan berdasarkan tahapan proses keperawatan. Pada umumnya semakin tinggi pendidikan seseorang maka semakin baik pula pengetahuanya (Wied, 1996 dalam Hendra, 2008).

Perencanaan keperawatan dibuat untuk mencapai tujuan dan kriteria hasil yang diharapkan guna mengatasi etiologi dan menyelesaikan masalah keperawatan. Intervensi dibuat secara spesifik dan operasional yang terdiri dari aktivitas apa yang akan dilakukan, bagaimana, seberapa sering, dan lebih baik lagi jika teridentifikasi siapa yang melakukan. Prinsip tersebut perlu dilakukan supaya tiap perawat yang melihat perencanaan keperawatan mudah untuk melakukannya atau mengaplikasikan rencana tersebut. Setelah tindakan telah dilakukan, tiap intervensi dievaluasi berdasarkan respon pasien terhadap tiap tindakan yang telah diimplementasikan dan mengacu atau berorientasi pada kriteria hasil yang telah ditetapkan.

Perencanaan keperawatan dibuat untuk mencapai tujuan dan kriteria hasil yang diharapkan guna mengatasi etiologi dan menyelesaikan masalah keperawatan. Intervensi dibuat secara spesifik dan operasional yang terdiri dari aktivitas apa yang akan dilakukan, bagaimana, seberapa sering, dan lebih baik lagi jika teridentifikasi siapa yang melakukan. Prinsip tersebut perlu dilakukan supaya tiap perawat yang melihat perencanaan keperawatan mudah untuk melakukannya atau mengaplikasikan rencana tersebut. Setelah tindakan telah dilakukan, tiap intervensi dievaluasi berdasarkan respon pasien terhadap tiap tindakan yang telah diimplementasikan dan mengacu atau berorientasi pada kriteria hasil yang telah ditetapkan.

Perencanaan keperawatan disusun berdasarkan diagnosa keperawatan. Komponen perencanaan keperawatan meliputi (Nursalam, 2012) :

a. Prioritas masalah dengan kriteria : masalah-masalah yang mengancam kehidupan merupakan prioritas pertama, masalah-masalah yang mengancam kesehatan seseorang adalah prioritas kedua, masalah-masalah yang mempengaruhi perilaku merupakan prioritas ketiga.

b. Tujuan asuhan keperawatan dengan : spesifik, bisa diukur, bisa dicapai, realistik, ada batas waktu. 
c. Rencana tindakan dengan kriteria : disusun berdasarkan tujuan asuhan keperawatan, melibatkan pasien/keluarga, mempertimbangkan latar belakang budaya pasien/keluarga, menentukan alternatif tindakan yang tepat, mempertimbangkan kebijaksanaan dan peraturan yang berlaku, lingkungan, sumberdaya dan fasilitas yang ada, menjamin rasa aman dan nyaman bagi pasien, kalimat instruksi, ringkas, tegas dengan bahasanya mudah dimengerti.

Fungsi Perencanaan. Manfaat dari fungsi perencanaan yaitu :

a) Memperkenalkan tujuan perencanaan sebagai alat untuk mencapai keberhasilan tujuan dan sasaran. Oleh karena itu seorang kepala ruangan harus membuat perencanaan yang terdokumentasi dengan baik.

b) Perencanaan berguna menilai efektifitas suatu pekerjaan dan juga efisiensi dalam penggunaan sumber daya manusia dan alat.

c) Tujuan perencanaan adalah membantu kepala ruangan ketika terjadi situasi kritis sehingga kepala ruangan mampu melihat prioritas tugas yang akan didahulukan atau tidak.

d) Perencanaan membantu kepala ruangan dalam mengatur biaya operasional di ruangan keperawatan. Sehingga bermanfaat membantu kepala ruangan untuk melihat kembali apa yang telah dilakukan pada waktu lampau dan yang akan datang sehingga melalui perencanaan yang baik membantu situasi perubahan dan inovasi.

e) Perencanaan sebagai alat pengontrol yang baik, melihat penyimpangan- penyimpangan dari awal dan mengarahkan pada alternatif pemecahan masalah.

Diagnosis keperawatan merupakan keputusan klinik tentang respon individu, keluarga dan masyarakat tentang masalah kesehatan aktual atau potensial, dimana berdasarkan pendidikan dan pengetahuanya, perawat secara akuntabilitas mengidentifikasi dan memberikan intervensi untuk menjaga, menurunkan, membatasi, mencegah, dan merubah status kesehatan pasien. Diperlukan kemampuan analisis yang tinggi dalam merumuskan diagnosa keperawatan. Namun perawat sering mengalami kesulitan dalam melaksanakan asuhan keperawatan dan pada kasus lain data dikumpulkan tanpa menyadari mengenai diagnosanya. Diagnosa keperawatan yang dilakukan perawat diharapkan dengan menggunakan sistem yang relevan. Syarat dari diagnosa keperawatan ialah perumusan jelas dan singkat dari respon pasien terhadap situasi yang dihadapi, spesifik dan akurat, memberikan arahan pada asuhan keperawatan, dapat dilakukan oleh perawat dan mencerminkan keadaan kesehatan pasien.

Intervensi keperawatan dibuat untuk mencapai tujuan dan kriteria hasil yang diharapkan guna mengatasi etiologi dan menyelesaikan masalah keperawatan. Intervensi dibuat secara spesifik dan operasional yang terdiri dari aktivitas apa yang akan dilakukan, bagaimana, seberapa sering, dan lebih baik lagi jika teridentifikasi siapa yang melakukan. Prinsip tersebut perlu dilakukan supaya tiap perawat yang melihat perencanaan keperawatan mudah untuk melakukannya atau mengaplikasikan rencana tersebut. Setelah tindakan telah dilakukan, tiap intervensi dievaluasi berdasarkan respon pasien terhadap tiap tindakan yang telah diimplementasikan dan mengacu atau berorientasi pada kriteria hasil yang telah ditetapkan. 
Implementasi adalah pengelolaan dan perwujudan dari rencana keperawatan yang telah di susun pada tahap perencanaan. Ukuran intervensi keperawatan yang diberikan kepada klien terkait dengan dukungan, pengobatan, tindakan untuk memperbaiki kondisi, pendidikan untuk klien-keluarga, atau tindakan untuk mencegah masalah kesehatan yang muncul dikemudian hari. Untuk kesuksesan pelaksanaan implementasi keperawatan agar sesuai dengan rencana keperawatan, perawat harus mempunyai kemampuan kognitif (intelektual), kemampuan dalam hubungan interpersonal, dan keterampilan dalam melakukan tindakan. Proses pelaksanaan implementasi harus berpusat kepada kebutuhan klien, faktor-faktor lain yang mempengaruhi kebutuhan keperawatan. Tahapannya yaitu :

1) Mengkaji kembali klien/pasien.

2) Menelaah dan memodifikasi rencana perawatan yang sudah ada.

3) Melakukan tindakan keperawatan.

Perawat mengimplementasikan tindakan yang telah di identifikasi sesuai rencana asuhan keperawatan. Asuhan keperawatan dilaksanakan berdasarkan kaidah-kaidah keperawatan atau kewenangan pelayanan keperawatan melaksanakan pengkajian keperawatan kepada individu di sarana kesehatan yang meliputi status bio-psiko-sosial-kultural dan spiritual klien, merumuskan diagnosis keperawatan terkait dengan fenomena tidak terpenuhinya kebutuhan Implementasi ini mencapai tujuan yang telah ditetapkan dan partisipasi klien dalam tindakan berpengaruh pada hasil yang diharapkan. Bila proses keperawatan dilakukan dengan tepat, keberhasilan dalam memberi asuhan keperawatan yang berkualitas dapat tercapai. Tercapainya pemberian asuhan keperawatan yang berkualitas akan berpengaruh pada kepuasan pasien.

\section{PENUTUP}

Dapat disimpulkan bahwa Proses keperawatan adalah salah satu metoda efektif pemecahan masalah yang dilakukan perawat terhadap klien dengan pendekatan metodologi ilmiah. Perawat dalam memberi pelayanan menggunakan pendekatan asuhan keperawatan tujuannya untuk agar meningkatkan derajat kesehatan pasien dan keluarga serta memberikan perawatan yang professional. Pengetahuan perawat berpengaruh terhadap proses keperawatannya. Sebelum melakukan proses keperawatan, perawat melakukan tahapan intervensi atau perencanaan untuk mencapai hasil yang diinginkan. Perawat harus mempunyai kemampuan kognitif, kemampuan dalam hubungan interpersonal dan keterampilan dalam melakukan tindakan. Perawat dalam memberi pelayanan menggunakan pendekatan asuhan keperawatan.

Intervensi keperawatan dibuat untuk mencapai tujuan dan kriteria hasil yang diharapkan guna mengatasi etiologi dan menyelesaikan masalah keperawatan. Intervensi dibuat secara spesifik dan operasional yang terdiri dari aktivitas apa yang akan dilakukan. Setelah melakukan perencanaan, dilakukan proses implementasi keperawatan yang disesuaikan dengan rencana keperawatannya. 


\section{DAFTAR PUSTAKA :}

Sari, I. P. (2016). Hubungan Pengetahuan Perawat Tentang Model Asuhan Keperawatan Metode Tim Dengan Implementasinya Di Ruang Bedah Flamboyan Rsud Dr Soetomo Surabaya. Medica Majapahit. Vol 8(2). 74-79

Supratti \& Ashriady. (2016). Pendokumentasian Standar Asuhan Keperawatan Di Rumah Sakit Umum Daerah Mamuju, Indonesia. Jurnal Kesehatan MANARANG Vol. 2(1). 44-51

Yeni, F. (2014). Pengaruh Pelatihan Proses Keperawatan Terhadap Dokumentasi. NERS JURNAL KEPERAWATAN. Vol 10(1). 20-27

Koerniawan, D., Daeli, E, N \& Srimiyati. (2020). Aplikasi Standar Proses Asuhan Keperawatan : Diagnosis, Outcome, Dan Intervensi Pada Asuhan Keperawatan. Jurnal Keperawatan Silampari. Vol 3(2). 739-751

Potter \& Perry. (2005). Buku Ajar Fundamental Keperawatan : Konsep, Proses, dan Praktik. Edisi 4. Jakarta : EGC.

Nursalam. (2011). Proses dan Dokumentasi Keperawatan : Konsep dan Praktik (Edisi 2). Jakarta : Salemba Medika.

Christina, P., Indracahyani, A., \& Yatnikasaria, A. (2019). Analisis Ketidaksinambungan Dokumentasi Perencanaan Asuhan Keperawatan: Metode Ishikawa. Jurnal Ilmiah Kesehatan (JIK). Vol 12(2). 518-524

Siswanto, L. M., Hariyati, R. T. S \& Sukihananto, S. (2013). Faktor-faktor Yang Berhubungan Dengan Kelengkapan Pendokumentasian Asuhan Keperawatan. Jurnal Keperawatan Indonesia. Vol 16 (2)

Butar-Butar, J., \& Simamora, R. H. (2016). Hubungan Mutu Pelayanan Keperawatan dengan Tingkat Kepuasan Pasien Rawat Inap di RSUD Pandan Kabupaten Tapanuli Tengah. Jurnal Ners Indonesia, 6(1), 50-63.

Simamora, R. H. (2005). Hubungan Persepsi Perawat Pelaksana Terhadap Penerapan Fungsi Pengorganisasian Yang Dilakukan Oleh Kepala Ruangan Dengan Kinerjanya Diruang Rawat Inap RSUD Koja Jakarta Utara (Doctoral dissertation, Tesis FIK UI, Tidak dipublikasikan).

Kasim, M.et.al. (2016). Peningkatan Kualitas Pelayanan Dan Pendokumentasian Asuhan. NurseLine Journal. Vol 1(1). 63-72

Miladiyah, N \& Mustikasari, Dewi. G(2015). Hubungan Motivasi Dan Komitmen Organisasi Dengan Kinerja Perawat Dalam Pelaksanaan Dokumentasi Asuhan Keperawatan, Jurnal. Keperawatan Indonesia. Vol 18(1). 9-16. 
Gunawan., Anjaswarni, T \& Sarimun. (2017). Hubungan Pengetahuan Dengan Kinerja Perawat Dalam Melaksanakan Asuhan Keperawatan Di Ruang Rawat Inap Rumah Sakit Tingkat II dr. Soepraoen Malang. Nursing News. Vol 2(2). 195-205

Widuri., Maryadi \& Astuti, D, L. (2017). Hubungan Tingkat Pengetahuan Perawat Dengan Kepatuhan Melaksanakan ASKEP Di Ruang Rawat Inap RS JIH Yogyakarta. MIKKI. Vol 05(01). 69- 76 